\title{
Peertechz
}

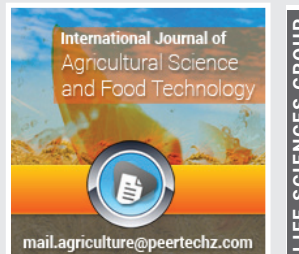

\section{Global role of plant breeding in tackling climate change}

\section{Temesgen Begna*}

Ethiopian Institute of Agricultural Research, Chiro National Sorghum Research and

Training Center P. O. Box 190, Chiro, Ethiopia
Accepted: 13 July, 2021

Published: 16 July, 2021 Institute of Agricultural Research, Chiro National Sorghum Research and Training Center P. O. Box 190, Chiro, Ethiopia, E-Mail: tembegna@gmail.com

Keywords: Climate change; Climate vulnerability; Adaptation; Mitigation; Climate smart; Food security https://www.peertechzpublications.com

\section{Check for updates}

\begin{abstract}
Nowadays, several global major production constraints of crop plants are identified: climate change, rapid population growth, increasing demand for food, reduction biodiversity, increasing demand for agricultural inputs and other multiple factors simultaneously affect crop plant production and productivity. These all production impediments are resulted substantial yield reduction across the world. Currently, climate change is becoming a serious challenge across the world with significant threats of food security, ecosystems, economic stability, and water resources. Climate change is also impacting the world through hampering the productivity; particularly the tropical regions of the world are suffering from drought and heat to develop and produce the high yielding crops during the crop life cycle. Climate change is caused by different agents, mainly greenhouse gas emissions from natural systems and human activities and shift in climate patterns and composition. Climate change has a potential to adversely affect agricultural productivity to the irreversible level and drives to hunger of millions of the global community. However, plant breeding was playing key roles in tackling production hindrance of crop plants through developing high yielding and resistance crop varieties against the production constraints. Plant breeding is the science improvement of crop plants for quantitative and qualitative traits and developing improved resistance crop technologies against biotic and abiotic stresses. These days, climate adaptation and mitigation strategies are developed and used to overcome the drastic effect of climate change on food security and livelihoods of the world communities. Climate adaptation and mitigation are the most important and an interdependent strategy that uses for complement one another in tackling the impact of climate change and pave the way for sustainable survival of earth's inhabitants. Climate adaptation has direct relation with the reduction of the negative impact of climate change through developing resilient crop plants to climate change whereas mitigation is devise to overcome causes and reduction of the possible impacts of climate change. Climate change affects food security in various ways, especially through impacting on all four components of food security (availability, accessibility, affordability, utilization and nutritional value and food system stability), through impacting on crop production and yield, through impacting on water availability, through impacting on fisheries production, through impacting on agricultural pests and through impacting on livestock production. Generally, plant breeding has profound impact on food production and will continue to play a vital role in the food security. Plant breeding is primarily relied on presence of substantial genetic variations to address the maximum genetic yield potential of the crops and exploitation of these variations through effective selection for improvement.
\end{abstract}

\section{Introduction}

Globally, there are several major production constraints identified with substantial influence on crop plants production and productivity. Among them, climate change, population growth and improved agricultural inputs are the most important production constraints across the world. The world population growth is increasing geometrically from year to year while crop productivity is increasing arithmetically, hence the problem of feeding these huge population is becoming formidable due to imbalance occurred between the population growth and crop productivity. The problem of this imbalance is happened due to drastic impact of climate change and associate effects. The assurance of global food security is challenge due to drastic climate change, reducing arable land and increasing population growth which expected to reach 8.6 billion in 2030 and 10 billion by 2050 [1]. Agriculture is faced for many challenges such as human population growth, climate change, malnutrition, poverty, hunger and other stressors. Overcoming these difficult challenges will be harder in the absence plant genetic improvement to increase agricultural productivity through addressing the problem of yield reduction and its links with pest management and climate change. Hence, agriculture must change to meet the rising demand of global population by the transition of agricultural growth to effective modern agricultural development [2].

Nowadays, the world population growth rates by passed the linear increment in food production. Hence, the crop productivity should be produced in the next coming future decades by $70 \%$ in order to feed human population adequately [3]. The rapid and unprecedented increase in human population requires the increasing of linear rates in annual food production by $37 \%$ and is tremendously decreased by the effects of climate 
change and crop production variation [4]. Simultaneously, climate change is significantly affecting climate composition in increasing temperature, changing rainfall pattern, ozone depletion and increasing $\mathrm{CO}_{2}$ level which hampered agricultural productivity [5]. Rapid economic growth is bringing significant income growth that accelerates economic transition toward consumption of different agricultural products [6]. Agriculture should produce almost $60-100 \%$ more food in 2050 than the current production [7]. Hence, the goal of achieving in producing enough food to meet the increasing demand for ensuring food security must be tackled despite climate change that associated with increase in temperature, water scarcity and land, which are predicted to have substantial impacts on the production of sufficient food.

Plant breeders successfully increased in food production for the last few centuries through different breeding strategies and procedures. However, agricultural productivity is reduced due to monoculture practices, which has significant reduction in genetic diversity and become serious problem in producing adequate agricultural food [8]. The integration of conventional plant breeding with advanced agronomic practices had played a pivotal role in achieving tremendous genetic gains of crop yields between 1960 and 2015. The combined utilization of improved varieties with irrigation, mechanized agricultural tools and excessive use of synthetic fertilizers to the first green revolution to increase productivity. However, the yield boosting as result of green revolution are decreasing for different major food crops due to various problems [9]. The present trend of annual yield increment for major crops of between 0.9 and $1.6 \%$ is not sufficient to meet requirements in the near future [10]. Therefore, meet the global food demand, the yield should be increased by $2.4 \%$ annual yield gain [10].

Hence, the development of superior varieties with climate change resilient crops is necessarily important for increasing productivity with parallel to increasing human population. In the rapid increment of world population, the agricultural productivity should be increased to overcome food security problems. Therefore, conventional crop plant improvement should be integrated with marker assisted breeding procedures to address the serious challenges of the world through enhancing crop genetic improvements [11]. To achieve fast and agricultural advancement in terms of production and productivity in the short period of time, the integration of marker assisted plant breeding is very crucial in the future world. It is difficult to overcome the global challenges of climate change in the absence of integration of biotechnology into plant improvement to enhance crop yields through addressing yield reduction and associated problems [12]. Advanced breeding strategies is very important in improving crop productivity and combating poverty, hunger and enhancing the living standards of the people through increasing yields of different crops [13].

Nowadays, genomic research is playing a pivotal role in crop improvement, particularly in identifying genetic variability and desirable traits as well as characterization of different crop genetic materials for abiotic and biotic stress resistance. Currently, the development of genome editing technologies, especially CRISPR/Cas, opened new routes of fast and precise genome modification for the betterment advancing the knowledge of improvement. Genome editing is playing significant role in transmitting, insertion and deletion of new sequence at desired location in the target genome [14]. It is possible to modify the known genes that control important traits selectively through genome editing to manipulate the phenotypes. This day, several genomic edited crops are entered into commercial markets in many developed countries like USA in addition to drought and salt tolerant varieties [15]. Urgently, crop plant improvement with the help of potential genomic approaches is very decisive for the development of climate change resilient crops.

Conventional plant breeding is working for the satisfaction of people in both quantitative and qualitative traits, however it should be integrated with different biotechnological techniques to advance crop genetic improvement and hastening the breeding cycle to satisfy the peoples demand to advanced level. Molecular breeding is defined as the improvements of genetic materials with help of molecular biotechnologies, particularly molecular markers in combination with genomics and linkage mapping [15]. Plant breeding is dealing with biological traits which can be transmitted from generation to another for further improvement against climate changes that adversely affecting crop plants. Generally, plant breeding primarily depends on presence of substantial genetic variation to address the maximum genetic yield potential of the crops and exploitation of this variation through effective selection for improvement. The availability of genetic variation is the key prerequisite to successful plant breeding. Plant breeding is focusing on the creation of genetic variation and applying appropriate selection procedures for improvement of quantitative and qualitative characteristics.

Climate change is the global phenomenon which is characterized by the changes of climate composition or elements (temperature, precipitation, and wind) that are especially caused by human activities [16]. It is caused due to change in each and every component of climate that includes: atmosphere, hydrosphere, biosphere, cry sphere and lithosphere or due to the complex interaction of all these components [17]. There are two major causes of climate changes. The first and most important cause is natural causes which deals with changes in solar activity, volcanic eruption, sea water temperature, ice cap distribution, westerly waves and atmospheric waves whereas artificial cause includes deforestation, carbon dioxide emission from industry and agricultural production activities, acid rain and the destruction of the ozone layer by Freon gas and greenhouse gases [18]. Greenhouse gases caused global warming which increases the Earth's temperature and started from the time of the industrial revolution. Greenhouse gas effect mainly include carbon dioxide $\left(\mathrm{CO}_{2}\right)$, methane $\left(\mathrm{CH}_{4}\right)$, nitrous oxide $\left(\mathrm{N}_{2} \mathrm{O}\right)$, hydro-fluorocarbon (HFCs), per fluorocarbon (PFCs) and sulfur hexafluoride ( $\left.\mathrm{SF}_{6}\right)$.

Agricultural production is encountering different challenges, particularly in semi-arid regions of the world. The major challenges of agricultural production are increasing 
population growth, economic fluctuation, water scarcity or drought and climate change [19]. All these production constraints are directly affecting yield stability and resulting in world food insecurity [20]. Genetic diversity has paramount role in the perpetuation of a species through offering adaptation mechanisms to biotic and a biotic environmental stresses and enables change in the genetic composition to cope with changes in the environment [21]. Plant genetic diversity is very critical in the continuation of agricultural development with significant improvement in different morphological and agronomical characteristics. Agriculture and climate change have strong correlation, which implies climate change has the adverse effect on the agricultural production of the world. The objective of the paper was to understand the role of plant breeding in tackling the formidable and catastrophic problems of climate change on agriculture productivity.

\section{Climate change and agriculture}

Agriculture and climate has strong correlation and interdependent to each other. Agriculture is affected with adverse effects of climate change either directly or directly [22]. Climate fluctuation and variability have very significant adverse effects on food self-sufficiency and security. The impact of climate change is potentially threatening crop production, but also offering opportunities for significant improvement. Ensuring the food security is a mission of global agricultural and forestry systems which is anticipated to develop high yielding crops to meet the increasing demand of human population in the future [23]. Agricultural productivity is significantly alleviated due to climate change during the past few decades. In many tropical and mid-latitude countries, the climate modeling studies suggested that climate change will adversely affect food crop yield potential [24]. Therefore, increasing in climate change is going to decrease the quantity and quality of food crops and forage [25]. The rising of extreme weather condition will likely continues in increasing price and yield volatility which affects the livelihoods and putting food security at risk in the future [26]. The increasing world demand for agricultural products like food, fuel and fiber will continues to increase because of climate change, growth in human population, changes in food habit and the need for alternative energy sources while there is no more or less additional arable land available for agricultural expansion. Therefore, agriculture must produce and improve the crop plants to increase yields on the same amount of land through adapting more climates resilient crops.

\section{Climate smart agriculture}

Climate-smart agriculture is described as the transformation and reorientation of agricultural development under the new realities of climate change [27]. Climate-smart agriculture is also about sustainable and increasing agricultural productivity, developing climate resilient crops, alleviates greenhouse gas (mitigation) and improves achievement of national food security and development goals. There are three major interdependent climate smart agriculture components that used for achieving the principal goal of climate smart agriculture [27]. These components of climate-smart agriculture are tackling the bottlenecks of climate change that hampered the growing demand for agricultural production especially food, fuel and fiber [28]. Climate-smart agriculture is playing significant role in providing the optimum services like economic development, food security, combating poverty, poverty reduction, climate change adapted crops and improving agricultural productivity.

Three themes of climate smart agriculture are identified the current gaps particularly in knowledge, climate related problems and interdisciplinary research and science-based actions: (1) farm and food systems, (2) landscape and regional issues and (3) institutional and policy aspects. The first two components describes crop physiology and genetics, mitigation and adaptation for livestock and agriculture, barriers to adoption of CSA practices, climate risk management and energy and biofuels (theme-1); and modeling adaptation and uncertainty, achieving multifunctionality, food and fishery systems, forest biodiversity and ecosystem services, rural migration from climate change and metrics (theme-2). The third describes in designing research that bridges disciplines, integrating stakeholder input to directly link science, action and governance. Climate-smart agriculture has developed to a set of strategies to meet the agricultural challenges by increasing resilience to weather extremes, adapting to climate change and decreasing agriculture's greenhouse gas emissions that contribute to global warming [29]. Climate-smart agriculture is continuously supporting the transition for agricultural systems ranging from smallholders to transnational coalitions [30] Figure 1.

\section{Productivity}

The goal of climate smart agriculture is continuously boosting agricultural productivity and enhancing incomes from livestock, crops and fish without harming the environment. Climate smart agriculture stands for enhancing nutritional and food security. Improving productivity is a key issues related to raising productivity for sustainable intensification of agriculture. Food production is the largest cause of global environmental change being responsible for up to $30 \%$ of global greenhouse gas emission and $70 \%$ of freshwater use [31].

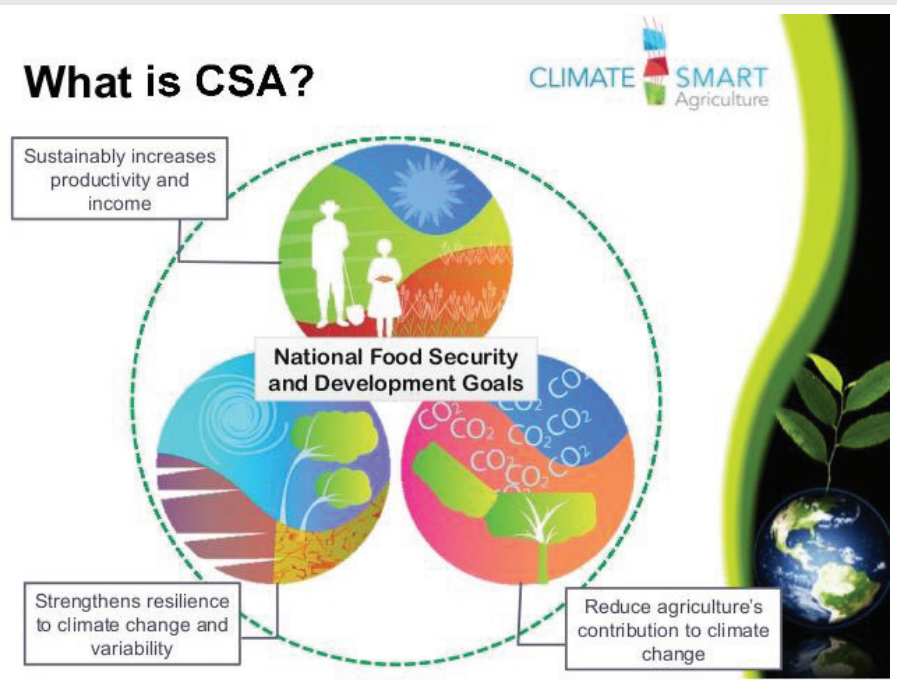

Figure 1: Major components of climate smart agriculture. Source: Seminar on Climate Change and Risk Management, 2018 


\section{Adapting to climate change}

Climate change adaptation is the resilience of climate change through reducing the vulnerabilities in biological and social aspect. Adaptation strategy is primarily developed to overcome the climate change effects especially in drought-prone areas [32]. Climate change adaptation is playing very critical role in reduction of global warming and vulnerabilities in the social and biological system. Adaptation to climate fluctuation is very critical issues in the food security discourse. Adaptability is essentially relying on the availability of genetic variability within and between crop species. The largest genetic variation of crop species offer the greater opportunities for improvement to adapt to environmental conditions. Agriculture productivity and growth are mainly susceptible to different problems especially climate change, extreme weather conditions and changing patterns of precipitations. Extreme temperature at critical growth stages can cause grain sterility and yield reduction [33]. Adaptation is the key factor in prevention of risks in agriculture related with climate change and helps in mitigating the negative impact of climate change. Adaptation strategies is playing very critical pivotal role through offering opportunity to tackle climate change challenges and sustain the improvement program [34]. Adaptation is also about the development of early maturing, drought and heat tolerant under climate change to sustain productivity. The new cultivars would increase the production per unit area under moisture stress and extreme temperatures [35].

Developing new varieties is the key options for adaptation of agriculture to climate change. The adaptation of agriculture to climate change needs more complementary strategies to develop new superior technologies to make agriculture resilient to climate change within the current footprint [27]. Conventional plant breeding is depending on phenotypic selection whereas genomics research is very important in developing the right adapted genotypes for the right environments without environmental impacts that complicates conventional breeding [14]. Advances in tools for analysis of plant performance are also supporting the development of optimal agronomic practices [14]. Genetic diversity is defined as the availability of genetic variation which is heritable traits in a population of given species. For the development of climate resilient cultivars, the existence of genetic diversity in the form of wild species, related species, breeding stocks and mutant lines are the source of desirable alleles which assist plant breeders to adapt to new climates. The availability of genetic diversity directly related with presence of desired alleles and helps to develop in breeding climate resilient varieties.

To ensure the sustainability of food security and crop production is becoming serious and threatens due to severity of drought stress and global climate changes. The incorporation of the adapted natural genetic variations into breeding programs can enrich the current genetic diversity of stress tolerance and improve yield under stress [33]. In ensuring food and nutritional security, genetic diversity is contributing very amble quantity. Knowledge of genetic diversity of the genetic material is very critical in crop improvement. Effective selection is highly important in any crop improvement where the sufficient genetic variation is available for different characters. Crop genetic diversity has tremendous role in mitigating the impact of climate change and devising adaptation strategies of crop diversity to the severe climate change is not the only important to offer basic demand to human being but also plays a major role in ensuring its quality Table 1.

\section{Mitigation strategies to climate change}

Mitigation is defined as designation to intervention and reduces the drastic effects of climate change through decreasing the level of greenhouse gases which include carbon dioxide, nitrous oxide and methane released to the atmosphere. Breeding methods is contributing pivotal role to decrease the emissions of greenhouse gases like methane and nitrous oxide from different sources of soil and grazing animals and has a potential to directly capture carbon from the plants and soils. The genetic improvement of crops is playing the significant role in the enhancement of agricultural productivity. Genetics materials has been using in product quality and yield enhancement as well as mitigate climate change and decreasing the environmental impacts of agricultural productivity. Wherever and whenever possible, climate smart agriculture helps to decrease and remove greenhouse gas emissions. Mitigation strategies about avoiding deforestation from agriculture and increasing the potential to absorb $\mathrm{CO}_{2}$ from the atmosphere [41].

\section{Impact of climate change on food security}

Food security is defined as that all people at all times, have physical, social and economic access to sufficient, safe and nutritious food that meets their food preferences and dietary needs for an active and healthy life [42]. Food security depends on availability of food, access to food, and utilization of food [43]. The common definition of food security rests on three pillars: food availability, food access, food utilization and their stability [44]. Indicators used to measure food availability include crop production and food production indices, livestock ownership indices and national food balance sheets [45]. Access to food is the set of alternative commodity bundles that a person can command in society by using the totality of rights and opportunities that he or she faces [46].

Table 1: Climate change adaptations for the major food security crop plants.

\begin{tabular}{|c|c|c|}
\hline $\begin{array}{c}\text { Crop (s) } \\
\text { name }\end{array}$ & Adaptation & References \\
\hline Wheat & $\begin{array}{l}\text { Use of heat tolerant cultivars } \\
\text { Adjustment of planting dates } \\
\text { Optimum plant population }\end{array}$ & Ahmad I, et al. [33] \\
\hline Rice & $\begin{array}{l}\text { System of rice intensification with alternate } \\
\text { wetting and draying } \\
\text { Direct planting }\end{array}$ & $\begin{array}{l}\text { Weerakoon WMW, et } \\
\text { al. [36] }\end{array}$ \\
\hline Maize & $\begin{array}{c}\text { Raised bed planting } \\
\text { Early maturing cultivars } \\
\text { Precision nutrient management }\end{array}$ & CIAT, et al. [37] \\
\hline Cotton & $\begin{array}{l}\text { Heat and drought tolerant cultivars } \\
\text { Increase in plant population by } 18 \%\end{array}$ & $\begin{array}{l}\text { Rahman } \mathrm{MH} \text {, et al. } \\
\text { [38] }\end{array}$ \\
\hline Sugarcane & $\begin{array}{c}\text { Ratoon management } \\
\text { Pit planting }\end{array}$ & Singh J, et al. [39] \\
\hline Chickpea & $\begin{array}{c}\text { Integrated weed control } \\
\text { Agro-forestry (Wind barrier) } \\
\text { Improved crop varieties (early maturity) }\end{array}$ & Ratnam M, et al. [40] \\
\hline
\end{tabular}

Citation: Begna T (2021) Global role of plant breeding in tackling climate change. J Agric Sc Food Technol 7(2): 223-229. 
Food accessibility is defined as the existence of resources which includes legal, political, economic and social that an individual requires access food. Food utilization is using food sufficiently in through adequate diet, clean water, sanitation and healthcare to reach a state of nutritional well-being where all physiological needs are met. Food utilization is "the nutritional value of the diet, including its composition and methods of preparation; the social values of foods, which dictate what kinds of food should be served and eaten at different times of the year and on different occasions; and the quality and safety of the food supply, which can cause loss of nutrients in the food and the spread of food borne diseases if not of a sufficient standard [47]. Food stability is all about a population, household or individual must have access to adequate food at all times. The concept of stability therefore refers to the availability, access and utilization dimensions of food security.

All dimensions of food security are thus closely intertwined with agriculture production which is both source of food and source of income for rural households. Food security vulnerability to climate change refers to the propensity of the food system to be unable to deliver food security outcomes under climate change and food security vulnerabilities to climate change encompass the environmental, economic and social dimensions [48]. As a result of the cascading impacts and specific vulnerabilities to food security description, climate change impacts four dimensions of food security like availability, access, utilization and stability directly and indirectly [49]. All dimensions of food security are affected by climate change and food security depends not only on the direct impact of climate change on food production, but also on human development, economic growth, trade flows, and food aid policy [50]. Climate change has major implications on food security and livelihoods [51]. Climate change affects food security, water availability and productivity levels in Africa [52]. Climate change is expected to affect all of the components that influence food security: availability, access, stability and utilization Figure 2.

\section{Conclusion}

Climate change is affecting millions of people across the world, especially the most vulnerable by increasing the frequency and virulence of the extreme meteorological phenomena that cause crop yield reduction and population displacement. The main challenges from climate change to

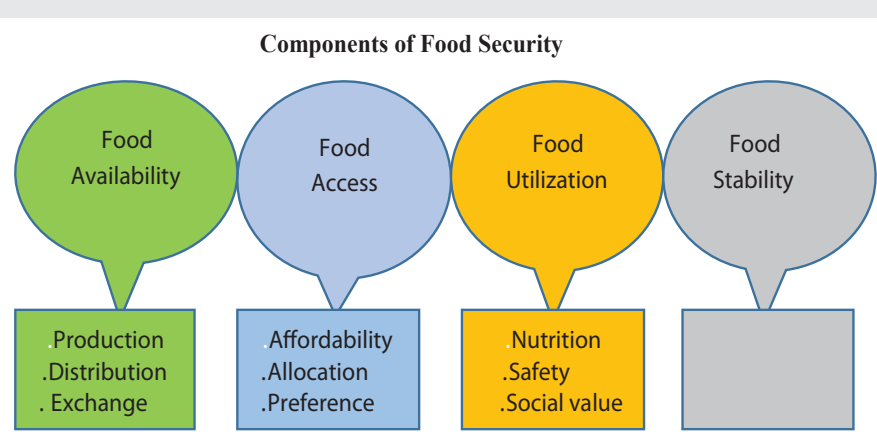

Figure 2: Basic Components of Food Security

Source: FAO, [21] agriculture and food production are the increased frequency and severity of abiotic stresses, and higher infestation of insects and diseases. Climate resilience is the ability of the plant or crop to survive and recover from the effects of climate change. Breeding climate-smart varieties responds not only to climatic requirements but also to the preferences of producers and end consumers. Climate-smart varieties allow producers to have very good harvests in an unfavorable environment marked by climate variability. Hence, the development of climate change resilient crops is necessary to tackle the real challenges of climate change and meet the challenge of feeding the growing world's population. The food production must be increased despite the projected decrease in arable land and unpredictable environmental conditions. As we know, land is shrinking but world population is increasing in a rapid phase, therefore modern agricultural practice is struggling to meet the level of primary productivity required to feed approximately 10 billion people by 2050 .

Plant Breeding has always played a pivotal role in human history from revolutionizing agriculture to feed the ever-growing population. The key role of plant breeding in agriculture is to develop a genetically superior genotype or variety, which is suitable for a specific as well as general cultivation of particular environment towards higher production. Recent developments in genomics in combination with high-throughput and precision phenotyping facilitate the identification of genes controlling critical agronomic traits. The discovery of these genes can now be paired with genome editing techniques to rapidly develop climate change resilient crops including plants with better biotic and abiotic stress tolerance and enhanced nutritional value. The progress in precise phenotyping and genotyping offers tremendous opportunities to develop crop varieties that are suit for better changing the climatic conditions, which ameliorate in boosting the plant breeding activities for developing climate resilient varieties or cultivars. Hence, development of climate resilient varieties utilizing smart breeding tools to ensures the food security in adverse climatic conditions. Ultimately, plant breeders may be able to design and then construct the required genotype by selecting the best allele for each locus to deliver performance in the target environment.

Future food production will rely on the continued development of new crop varieties including novel crops and new types of plant-based foods. Crop species that are currently underutilized will need research attention to be able to contribute to climate adaptation. This may require the domestication of new species and the more extensive use of crop wild relatives capturing much more of the available plant biodiversity. Strategies for the capture of novel variation may include the use of techniques such as gene editing to directly introduce novel alleles found in wild plants into domesticated crop varieties. This would allow the rapid and definitive evaluation of the genetic contribution of the introduced allele relative to the earlier much less effective and efficient approaches of extensive backcrossing.

Generally, the changes in the rainfall patterns, temperature, $\mathrm{CO}_{2}$ level and greenhouse gases resulting in the frequency and 
severity of extreme events such as flooding, drought, hail, and hurricanes etc. are major hindrance in achieving the food security for ever increasing population. In the face of ongoing and projected climate change, including higher temperatures and more erratic climate events across extensive regions over the globe, breeding of crop plants with enhanced yield potential and improved resilience to such environments is crucial for global food security. Improved plant varieties that can withstand diseases and pests with efficient use of fewer resources, exhibiting stable yields amidst stressful climate in near future could only help to achieve the goal of climate resilient agriculture. In order to be able to make contribution in climatic resilience, research attention is indispensable for currently underutilized crop species. The world population is increasing alarmingly, but productivity is reduced because of several production challenges. Hence, conventional plant breeding method alone cannot address the serious challenges that world facing. Therefore, in order to overcome the food security problems, conventional plant breeding should be assisted and integrated with various biotechnology developments to hasten the crop genetic improvements. To ensure the rapid and advanced agricultural development within short period of time, the incorporation of molecular marker in plant breeding very relevant in the future world.

\section{References}

1. Tomlinson I (2013) Doubling food production to feed the 9 billion: a critical perspective on a key discourse of food security in the UK. Journal Rural Studies 29: 81-90. Link: https://bit.ly/3kqLWRO

2. Satterthwaite D, McGranahan G, Tacoli C (2010) Urbanization and its implications for food and farming. Philosophical transactions of the royal society B: biological sciences 365: 2809-2820. Link: https://bit.ly/3wDHtNm

3. FAO (2009) How to Feed the World 2050: High-level Expert Forum. Global Agriculture Towards.

4. Beddington JR, Asaduzzaman M, Bremauntz FA, Clark ME, Guillou M, et al. (2011) Achieving food security in the face of climate change: Summary for policy makers from the Commission on Sustainable Agriculture and Climate Change.

5. Godfray HCJ, Crute IR, Haddad L, Lawrence D, Muir JF, et al. (2010) Food security: the challenge of feeding 9 billion people. Science 327: 812-818. Link: https://bit.ly/3wL9TVN

6. Tilman D, Clark M (2014) Global diets link environmental sustainability and human health. Nature 515: 518-522. Link: https://bit.ly/3eqYFiJ

7. Tilman D, Balzer C, Hill J, Befort BL (2011) Global food demand and the sustainable intensification of agriculture. Proc Natl Acad Sci U S A 108: 20260 20264. Link: https://bit.ly/3xNTMlq

8. Khoury CK, Bjorkman AD, Dempewolf H, Ramirez-Villegas J, Guarino L, et al. (2014) Increasing homogeneity in global food supplies and the implications for food security. Proceedings of the National Academy of Sciences 111: 4004006. Link: https://bit.ly/3x04Q8f

9. Grassini P, Eskridge KM, Cassman KG (2013) Distinguishing between yield advances and yield plateaus in historical crop production trends. Nat Commun 4: 2918. Link: https://go.nature.com/3z395gj

10. Ray DK, Mueller ND, West PC, Foley JA (2013) Yield trends are insufficient to double global crop production by 2050 . PloS one 8: e66428. Link: https://bit.ly/3xM8I9|
11. Varshney RK, Singh VK, Kumar A, Powell W, Sorrells ME (2018) Can genomics deliver climate-change ready crops. Curr Opin Plant Biol 45: 205-211. Link: https://bit.ly/3wJ2TbO

12. Scholes RJ, Biggs R (2004) Assessing biodiversity intactness multiple scales. Bridging scales and epistemologies: linking local knowledge and global science in multi-scale assessment.

13. Gruhn P, Paarlberg RL, Goletti F, Yudelman M (2000) Governing the GM crop revolution: policy choices for developing countries. Intl Food Policy Res Inst. Link: https://bit.ly/3km6Y35

14. Scheben A, Wolter F, Batley J, Puchta H, Edwards D (2017) Towards CRISPR/ Cas crops-bringing together genomics and genome editing. New Phytol 216: 682-698. Link: https://bit.ly/3ekptRR

15. Waltz E (2018) With a free pass, CRISPR-edited plants reach market in record time. Nat Biotechnol 36: 6-7. Link: https://bit.ly/3xMukmi

16. Bernhard GH, Neale RE, Barnes PW, Neale PJ, Zepp RG, et al. (2020) Environmental effects of stratospheric ozone depletion, UV radiation and interactions with climate change. Photochem Photobiol Sci 19: 542-584. Link: https://rsc.li/2TeJQbH

17. Gornall J, Betts R, Burke E, Clark R, Camp J, et al. (2010) Implications of climate change for agricultural productivity in the early twenty-first century. Philosophical Transactions of the Royal Society B: Biological Sciences 365: 2973-2989. Link: https://bit.ly/3xJ2sje

18. Ranaivoson A, Moncrief J, Venterea R, Rice P, Dittrich M (2012) Report to the Minnesota Department of Agriculture: Anaerobic Woodchip Bioreactor for Denitrification, Herbicide Dissipation, and Greenhouse Gas Mitigation." Minnesota Department of Agriculture.

19. Eigenbrode SD, Binns WP, Huggins DR (2018) Confronting climate change challenges to dryland cereal production: A call for collaborative, transdisciplinary research, and producer engagement. Front Ecol Evol 5: 164. Link: https://bit.ly/3rchzzd

20. Wang J, Vanga SK, Saxena R, Orsat V, Raghavan V (2018) Effect of climate change on the yield of cereal crops: A review. Climate 6: 41. Link: https://bit.ly/3wGEjIB

21. FAO F (2012) The state of world fisheries and aquaculture. Opportunities and challenges. Food and Agriculture Organization of the United Nations.

22. Luck J, Spackman M, Freeman A, Tre , bicki P, Griffiths W, et al. (2011) Climate change and diseases of food crops. Plant Pathology 60: 113-121. Link: https://bit.ly/36FopUm

23. Vermeulen SJ, Campbell BM, Ingram JS (2012) Climate change and food systems. Annual review of environment and resources 37: 195-222. Link: https://bit.ly/3xLr7ng

24. Knox J, Hess T, Daccache A, Wheeler T (2012) Climate change impacts on crop productivity in Africa and South Asia. Environmental Research Letters 7 034032. Link: https://bit.ly/3B8at3a

25. Myers SS, Zanobetti A, Kloog I, Bloom AJ, Carlisle EA, Dietterich LH, et al. (2014) Rising CO2 threatens food quality. Nature 510: 139-142. Link: https://bit.ly/3hHQ39y

26. Wheeler T, Von Braun J (2013) Climate change impacts on global food security. Science 341: 508-513. Link: https://bit.ly/2VFDDX4

27. Lipper L, Thornton P, Campbell BM, Baedeker T, Braimoh A, et al. (2014) Climate-smart agriculture for food security. Nature climate change 4: 10681072. Link: https://go.nature.com/2UfO08F

28. Palombi L, Sessa R (2013) Climate-smart agriculture: sourcebook. Climate smart agriculture: sourcebook. Link: https://bit.ly/3xJvuyZ

29. World Bank (2013) World development report 2014: Risk and opportunitymanaging risk for development. Link: https://bit.ly/3ifdZA8 
30. World Bank (2011) Increased Productivity and Food Security, Enhanced Resilience and Reduced Carbon Emissions for Sustainable Development. Link: https://bit.ly/3B9xqTH

31. Willett W, Rockström J, Loken B, Springmann M, Lang T, et al. (2019) Food in the Anthropocene: the EAT-Lancet Commission on healthy diets from sustainable food systems. Lancet 393P: 447-492. Link: https://bit.ly/3z7jOpZ

32. Smit B, Wandel J (2006) Adaptation, adaptive capacity and vulnerability. Global Environmental Change 16: 282-292. Link: https://bit.ly/2UTWiOo

33. Ahmed S (2018) Assessment of urban heat islands and impact of climate change on socioeconomic over Suez Governorate using remote sensing and GIS techniques. Egyptian Journal of Remote Sensing and Space Science 21 15-25. Link: https://bit.ly/3ritWcT

34. Fischer G, Shah MM, Van Velthuizen HT (2002) Climate change and agricultural vulnerability. International Institute for Applied Systems Analysis. Link: https://bit.ly/36EGYlj

35. Deressa TT, Hassan RM, Ringler C, Alemu T, Yesuf M (2009) Determinants of farmers' choice of adaptation methods to climate change in the Nile Basin of Ethiopia. Global Environmental Change 19: 248-255. Link: https://bit.ly/3eoMXW0

36. Weerakoon WMW, Mutunayake MMP, Bandara C, Rao AN, Bhandari DC, et al (2011) Direct-seeded rice culture in Sri Lanka: lessons from farmers. Field Crops Research 121: 53-63. Link: https://bit.ly/36Hfvpe

37. CIAT; World Bank; CCAFS and LI-BIRD (2017) Climate-Smart Agriculture in Nepal. CSA Country Profiles for Asia Series. Washington, D.C: International Center for Tropical Agriculture (CIAT); the World Bank; CGIAR Research Program on Climate Change, Agriculture and Food Security.

38. Rahman MH, Ahmad A, Wang X, Wajid A, Nasim W, et al. (2018) Multimodel projections of future climate and climate change impacts uncertainty assessment for cotton production in Pakistan. Agricultural and Forest Meteorology 253: 94-113. Link: https://bit.ly/3ifdndO

39. Singh J, Singh AK, Sharma MP, Singh PR, Srivastava AC (2011) Mechanization of sugarcane cultivation in India. Sugar Tech 13: 310-314. Link: https://bit.ly/3kCNelX

40. Ratnam M, Rao AS, Reddy TY (2011) Integrated weed management in chickpea (Cicer arietinum L.). Indian Journal of Weed Science 43: 70-72. Link: https://bit.ly/3eplHqt
41. Senapati N, Stratonovitch P, Paul MJ, Semenov MA (2019) Drought tolerance during reproductive development is important for increasing wheat yield potential under climate change in Europe. J Exp Bot 70: 2549-2560. Link: https://bit.ly/2UoXwe7

42. FAO (1996) Rome Declaration on World Food Security and World Food Summit Plan of Action. World Food Summit 13-17 November 1996. Link: https://bit.ly/3rb70fK

43. FAO (2000) Land resources and potential constraints at regional and country levels. Food and Agriculture Organization of the United Nations. Link: https://bit.ly/3kpdgz5

44. Ericksen P, Thornton P, Notenbaert A, Cramer L, Jones P, Herrero M (2011) Mapping hotspots of climate change and food insecurity in Renzaho AM, Mellor D (2010) Food security measurement in cultural pluralism: missing the point or conceptual misunderstanding Nutrition 26: 1-9.

45. Renzaho AM, Mellor D (2010) Food security measurement in cultural pluralism Missing the point or conceptual misunderstanding. Nutrition 26: 1-9. Link: https://bit.ly/3BbUh11

46. Sen A (1984) Resources, values and development. Link: https://bit.ly/3z5GCqo

47. FAO (2008) Challenges for Sustainable Land Management (SLM) for Food Security in Africa. 25th Regional Conference for Africa, Nairobi Kenya, Information Paper.

48. FAO (2016) Climate change and food security risks and responses. 1-46.

49. Turral H, Burke J, Faurès JM (2011) Climate Change, Water and Food Security. Food and Agriculture Organization of the United Nations Rome. Link: https://bit.ly/3wHV3zd

50. Jodie K, Page S, Kergna A, Kennan J (2009) Climate change and developing country agriculture: An overview of expected impacts, adaptation and mitigation challenges, and funding requirements. Link: https://bit.ly/3z0MCkb

51. Thompson J, Scoones I (2009) Addressing the dynamics of agri-food systems: an emerging agenda for social science research. Environmental Science \& Policy 12: 386-397. Link: https://bit.ly/3hHgvA4

52. Hope KR (2009) Climate change and poverty in Africa. International Journal of Sustainable Development \& World Ecology 16: 451-461. Link: https://bit.ly/2Ua7gzG

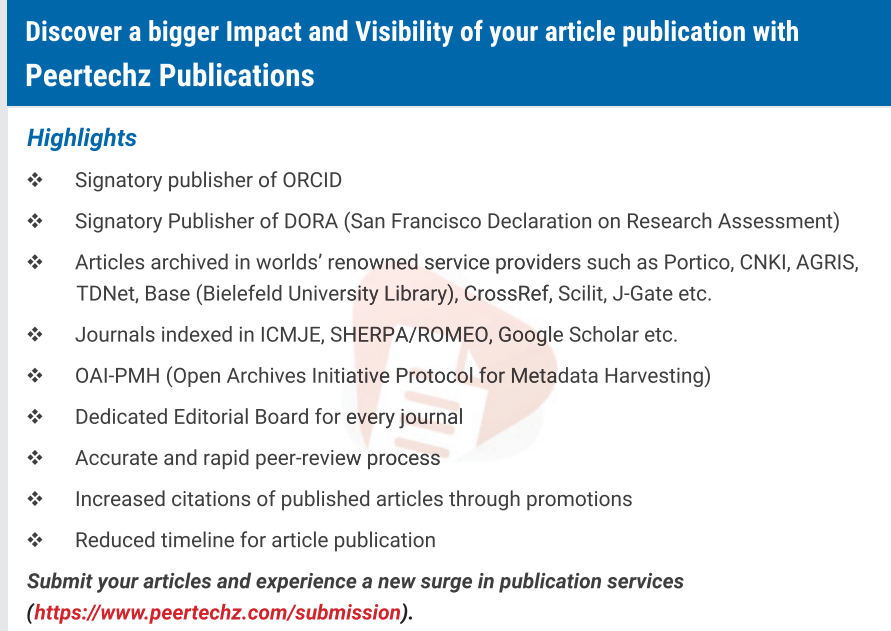

Peertechz journals wishes everlasting success in your every endeavours.

Copyright: @ 2021 Begna T. This is an open-access article distributed under the terms of the Creative Commons Attribution License, which permits unrestricted use distribution, and reproduction in any medium, provided the original author and source are credited.

Citation: Begna T (2021) Global role of plant breeding in tackling climate change. J Agric Sc Food Technol 7(2): 223-229. DOI: https://dx.doi.org/10.17352/2455-815X.000111 